\title{
Scientometric Analysis on the Developments of Archival Appraisal Theories
}

\author{
Ying $\mathrm{He}^{1}$ and Kun Tian ${ }^{2, *}$ \\ ${ }^{1}$ School of Management, Tianjin Normal University, 393 West Binshui Road, Xiqing District, Tianjin China 300387 \\ ${ }^{2}$ College of Software, Tianjin Normal University, 393 West Binshui Road, Xiqing District, Tianjin China 300387 \\ *Corresponding author
}

\begin{abstract}
The fundamental theory of Archival Science is Archival Appraisal Theory (AAT), and it has been undergoing substantial changes since 1990s. This paper uses Scientometric research methods and the related Knowledge-Mapping tool to analyze the citations between AAT journal articles and those from other disciplines. The objective is to identify the hot spots of AAT research and to summarize its developments from 1990 to 2017. We also make use of the results to extrapolate the developmental trends of AAT in the past thirty years from a macroscopic viewpoint. Our discoveries can be used by various research administrations as well as academic institutions to augment and fine-tune Archival Scienceresearch in order to meet the emerging demands in appraising modern archival works.
\end{abstract}

Keywords-social network analysis; knowledge management; science of science; citation analysis; research and development management; research governance

\section{INTRODUCTION}

Archival Appraisal Theory (AAT) had been invented as a result of the developments of modern archival works. The theory itself concerns various concepts such as value, utilization, appraisal, simplification, and benefits in appraising archives [1]. Archival characteristics of files and the characteristics of archival management are reflected in AAT [2]. Using the research methods of Scientometrics and the related Knowledge-Mapping tool, analysis on the developments of AAT from 1990 to 2017is made in this paper. Various AAT developments are identified and summarized, and we discover five trends of AAT developments through a macroscopic view.

\section{ARCHIVAL APPRAISAL THEORY AND ITS HISTORY OF DEVELOPMENT}

\section{A. What is Archival Appraisal?}

Archival appraisal is the practice to identify and assess the values of archives, in order to identify the valuable ones to hand over to an archival institution and to discard the worthless ones meanwhile. Archival appraisal directly determines whether or not an archive should be preserved or destroyed, and the determination itself is the most important and difficult aspect of archival management. [4][6][7][9]

\section{B. Developments of Archival Appraisal Theories}

A. "Age determination theory": In 1901, German archival scholar Mays McConnell put forward the notion that "elderly archives should be respected" and he proceeded to set an arbitrary amount of time for their preservations before destructions. McConnel, for the first time, also raised the idea that the provenance of an archive should be among the most important appraisal criteria. [17][8]

B. "Administrative official determination theory": In the 1920s, British archival scholar Hilary Jenkinson proposed that the archival workers ought not to be involved in the appraisal and destruction of archives. Instead, they should be done by administrative officials.[11]

C. "Function appraisal theory": In the 1930s, Polish archival scholar Carlin Sharansky proposed that the importance of the producers' positions and their functions in a governmental hierarchical system should be used to decide the values and retention periods of the archives they produced.[13][27]

D. "Archival dual values theory": In 1956 American archival scholar T. R. Schellenberg, known as "the father of archival appraisal theory", published his iconic work, the Principle and Technology: Modern Archives, and he proposed that public archives should have two different values: the value to government bodies producing the archive, "the first value", and the value to the users of other government bodies or individual users, "the second value". Specifically, the first value reflects an archive's administrative value, the legal value, the financial value and the technological value, while the second value reflects its evidential value, information value and intelligence value. The administrative officials from the government body producing an archive should be responsible for appraising the archive's first value, whereas its second value should be determined by archival workers. [14]

E. "Utilization determination theory": In 1960s and 1970s, American archival scholars Fez, Bridgetown, Clifford and Finch proposed that historians' actual and expected utilizations of archives should be the most important criteria for archival appraisal. [22][15]

F. "Social analysis and function appraisal theory": In early 1980s, German archival scholar Booms advocated that an archive should reflect the social values in its formation period. He also argued that these values should be indirectly determined through understanding of its creators' functions rather than be directly determined through the study of the social public opinions during the period. [19][24] 
G. "Literature strategy theory": In mid-1980s, American archival scholar Seymour Wales advocated that the starting point of archival appraisal shall no longer be the examination of an archive but the analysis of the backgrounds in which the archive was produced, especially as a response to the frequent changes of the archive-producing government bodies in modern society. [20]

H. "Macro-appraisal strategic theory": In late 1980s, Canadian archival scholar Terry Cook proposed that a variety of factors should be taken into consideration for archival appraisal such as the social structure, archival formation process, creators and their functions.[7][23][26]

\section{DATA SOURCES AND RESEARCH METHODOLOGY}

\section{A. Data Sources}

The Institute for Scientific Information (ISI) started to publish Science Citation Index (SCI) in 1964, and ISI brought an integrated system of academic information resources named "ISI Web of Knowledge". The core of this system is "Web of Science" (WOS) through which ISI's three most famous citation databases, Science Citation Index Expanded (the SCIE), Social Science Citation Index (SSCI) and Arts \& Humanities Citation Index (A\&HCI), can be directly accessed. These three citation databases cover the most important and influential research achievements in the world.

The journal articles from the above three databases of WOS were accessed with a default time span from January 1st 1990 to November 21st of 2017. The information retrieval was centered on the topic of "appraisal", and the query was "Subject = appraisal or appraise, publication time $=1990-2017$, select Social Sciences Citation Index (SSCI) and Arts \& Humanities Citation Index (A\&HCI), Lemmatization $=$ on, documental type $=$ article". 20870 articles were retrieved as a result. However, many of the journals articles containing the keywords were irrelevant to archival appraisal research. For example, an article from an archeology journal containing the keyword "appraisal" may only mean to describe and evaluate the new discoveries from an archeological excavation site and hence does not contribute to archival appraisal research. In order to eliminate such noises, the retrieval results were refined, and eventually 14470 articles were selected as source literatures.

\section{B. Research Methodology}

The interactions between different disciplines are reflected in the citations linking their articles. An article from one discipline citing the research results or study methods introduced by the articles from another discipline shows that the latter discipline informs the first one, which may use the cited results and methods to broaden and/or deepen its own research.

Such analysis is called Citation Analysis, a research method frequently employed in Scientometrics. Making use of graph theory, fuzzy sets, statistics and logical methods such as inference and induction, it analyzes citations on research objects, such as academic journals, conference papers and authors in order to forecast and evaluate the trends of scientific developments.

Knowledge-Mapping is the graphical display of the development processes and the structural relationships of scientific knowledge. [3][5][16][25] It makes use of visualization technologies to sort out and describe the relationships between scientific knowledge and the related patterns of knowledge evolution. [18][12] The developments of AAT in the last thirty years are visualized using VOSviewer1.4, the Knowledge-Mapping drawing tool, in this paper.

VOSviewer, written in the Java programming language, runs on most operating system platforms. [3][10][21]It is the primary tool for analyzing a Scientometrics networks. The program can be used to create maps of publications, authors, or journals based on a co-citation network or to create maps of keywords based on a co-occurrence network. The maps are created using the VOS mapping technique and the VOS clustering technique. VOSviewer can be used to view and explore the maps as well. It can show a map in various different ways, with each emphasizing a different aspect of the map.

\section{RESULTS}

After the text edit has been completed, the paper is ready for the template. Duplicate the template file by using the Save As command, and use the naming convention prescribed by your conference for the name of your paper. In this newly created file, highlight all of the contents and import your prepared text file. You are now ready to style your paper; use the scroll down window on the left of the MS Word Formatting toolbar.

\section{A. Analysis 1: Contributions of AAT Related Research Articles by Countries}

Table 1 shows that based on the total number of AAT related research articles produced by countries, USA and UK were the ones that are the most active in AAT related research with them together being responsible for more than three fifths of all the articles published during the period. Canada and Australia are also noticeable countries that had highly active AAT related research with each of them accounting for more than $8 \%$ of the articles published during the period.

TABLE I. TOP AAT RELATED RESEARCH ARTICLES BY COUNTRIES

\begin{tabular}{ccc}
\hline Countries/Areas & Count & Percentage \\
\hline USA & 6565 & $33.44 \%$ \\
UK & 6082 & $30.98 \%$ \\
Canada & 1907 & $9.71 \%$ \\
Australia & 1635 & $8.33 \%$ \\
Germany & 1146 & $5.84 \%$ \\
Netherlands & 1099 & $5.60 \%$ \\
Peoples R China & 633 & $3.23 \%$ \\
Italy & 611 & $3.11 \%$ \\
\hline
\end{tabular}




\begin{tabular}{cll}
\hline France & 608 & $3.10 \%$ \\
Switzerland & 566 & $2.88 \%$ \\
Spain & 488 & $2.49 \%$ \\
Belgium & 415 & $2.11 \%$ \\
Sweden & 355 & $1.81 \%$ \\
India & 297 & $1.51 \%$ \\
New Zealand & 246 & $1.25 \%$ \\
Brazil & 237 & $1.21 \%$ \\
Israel & 227 & $1.16 \%$ \\
Japan & 224 & $1.14 \%$ \\
South Africa & 217 & $1.11 \%$ \\
Denmark & 208 & $1.06 \%$ \\
\hline
\end{tabular}

\section{B. Analysis 2: The Citation Analysis of Cited Archival} Appraisal Theory

1) The knowledge mapping of disciplines citing AAT

Table 2 lists the frequency statistics of the disciplines citing AAT. It shows that AAT has been cited by many disciplines and thus it has impacts on those disciplines by varying degrees. Figure 1 is a mapping of the relationships among disciplines having cited AAT. The size of a ball on the map is proportional to the number of instances of citing AAT in the related discipline. Figure 2 is the density map of disciplines having cited AAT. Figure 1 and Figure 2 show that the top two disciplines (that cited AAT the most) are Business \& Economy and Psychology, which are followed by Social Science, Health Care Sciences \& Services, Environmental Sciences \& Ecology, etc.

TABLE II. FREQUENCIES OF DISCIPLINES CITING ARCHIVAL APPRAISAL THEORY (FREQUENCY>800)

\begin{tabular}{|c|c|c|c|}
\hline Freq. & Discipline & Freq. & Discipline \\
\hline 17418 & Business \& Economics & 1192 & Communication \\
\hline 14519 & Psychology & 1186 & $\begin{array}{c}\text { Information } \\
\text { Science \& } \\
\text { Library Science }\end{array}$ \\
\hline 3276 & $\begin{array}{c}\text { Social Sciences - Other } \\
\text { Topics }\end{array}$ & 1159 & Family Studies \\
\hline 2410 & $\begin{array}{c}\text { Health Care Sciences \& } \\
\text { Services }\end{array}$ & 1157 & $\begin{array}{l}\text { Neurosciences } \\
\& \text { Neurology }\end{array}$ \\
\hline 2127 & $\begin{array}{l}\text { Environmental Sciences } \\
\qquad \& \text { Ecology }\end{array}$ & 1077 & Urban Studies \\
\hline 2025 & $\begin{array}{l}\text { Public, Environmental } \\
\& \text { Occupational Health }\end{array}$ & 996 & Psychiatry \\
\hline 1964 & Computer Science & 995 & Social Work \\
\hline 1809 & Public Administration & 944 & Sociology \\
\hline 1695 & Engineering & 873 & $\begin{array}{l}\text { Education \& } \\
\text { Educational } \\
\text { Research }\end{array}$ \\
\hline 1421 & $\begin{array}{l}\text { Operations Research \& } \\
\text { Management Science }\end{array}$ & 835 & $\begin{array}{c}\text { Government \& } \\
\text { Law }\end{array}$ \\
\hline 1223 & Sport Sciences & & \\
\hline
\end{tabular}

2) The knowledge mapping of research focuses from the disciplines citing AAT

A keyword reveals the research focus of a scientific research, and the higher frequency one keyword has, the more attention its research focus received. Table 3 lists the frequencies of specifically cited AAT research focuses from the disciplines having cited AAT. Figure 3 is the mapping of relationships among research focuses. Figure 4 is the density map of research focuses from disciplines citing AAT. According to Table 3, Figure 3 and 4, the No.1 research focus is PERFORMANCE, at a frequency of 6092, which is commonly found in the disciplines of Business \& Economics, Human Resource Management, and Psychology. It follows that AAT has been applied to management evaluation theories, where PERFORMANCE is a high frequency word. The second research focus is MODEL, which has been found in many disciplines, at a frequency of 4661 , and those disciplines normally took advantage of AAT to build mathematic models in order to solve practical problems. The third research focus is BEHAVIOR that has been found in Psychology, at a frequency of 3040, and it follows that AAT have been employed by psychology to study behaviors.

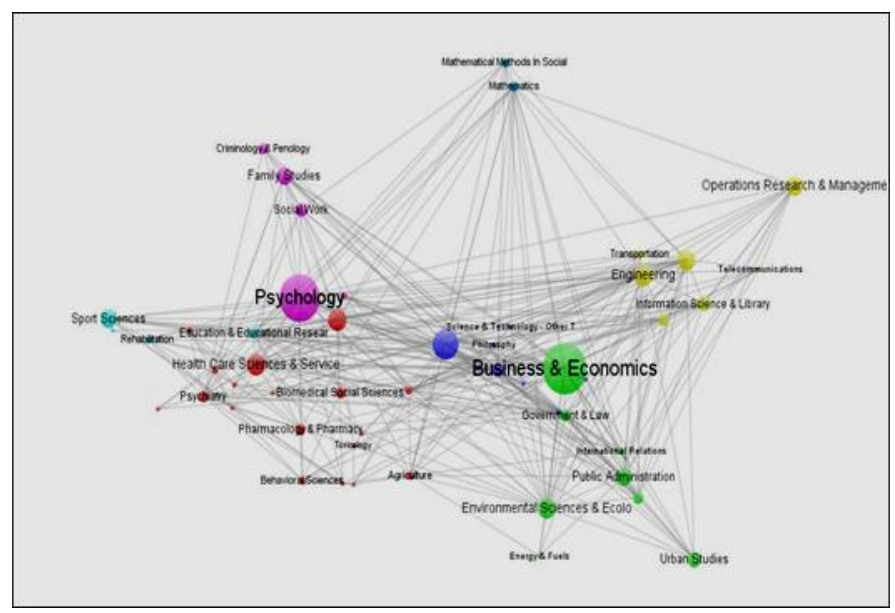

FIGURE I. MAPPING OF RELATIONSHIP BETWEEN DISCIPLINES CITING AAT

\section{Analysis 3: The Citation Analysis of Archival Appraisal Theory (Citing)}

1) The Knowledge-Mapping of disciplines cited by AAT

Table 4 is the frequency statistics of disciplines cited by AAT, and Figure 5 and 6 are respectively the mapping of relationship among disciplines cited by AAT and the density map of these disciplines. These maps show that AAT has referenced and borrowed ideas and research results from other disciplines, such as Business \& Economics, Psychology, Social Sciences, Public Administration, Information Science \& Library Science, and History. Since 1990s, these disciplines have become important knowledge sources for AAT, influencing its developments. 


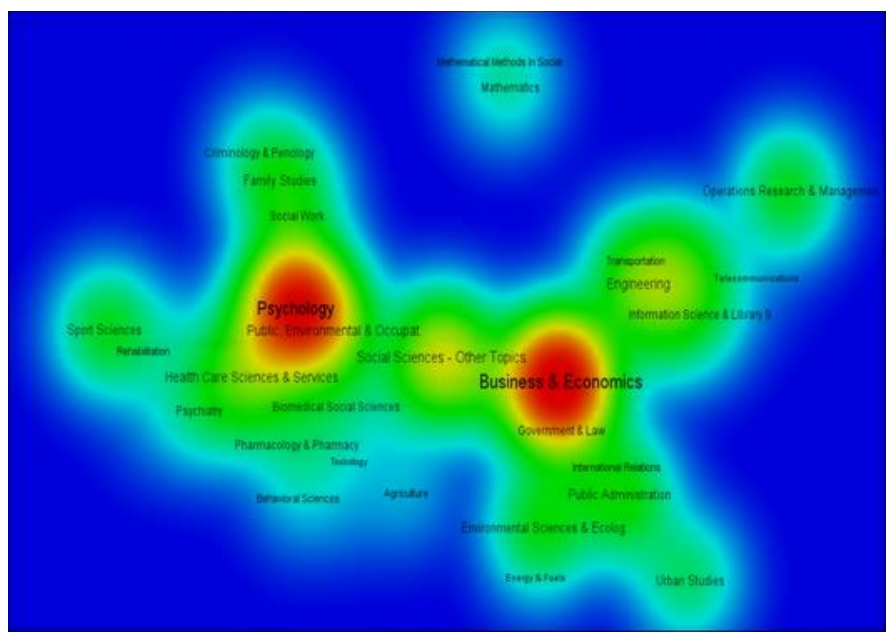

FIGURE II. DENSITY MAP OF DISCIPLINES CITING AAT

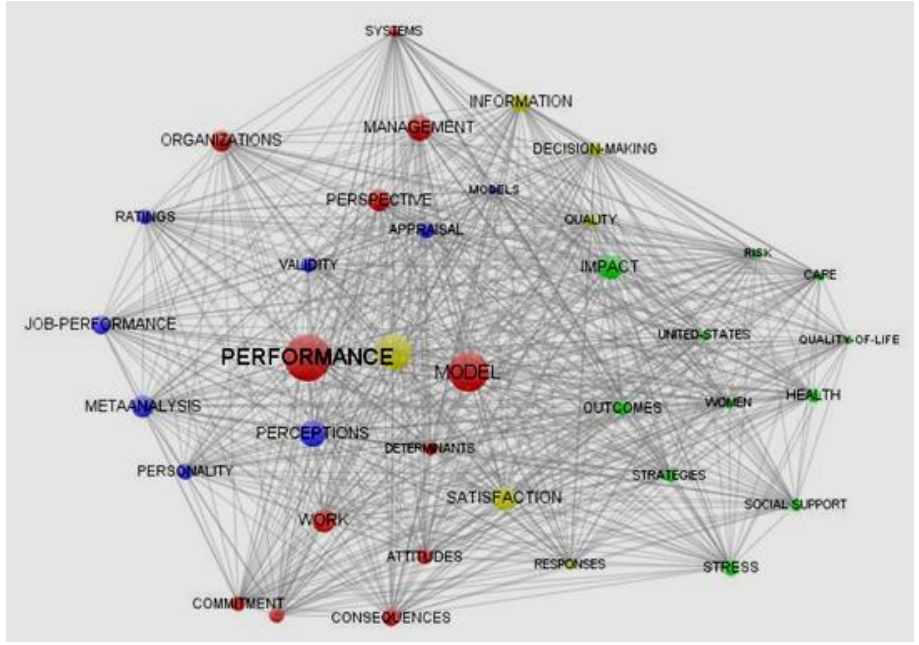

FIGURE III. MAPPINGOF RELATIONSHIP BETWEEN RESEARCH FOCUSES FROM DISCIPLINES CITING AAT

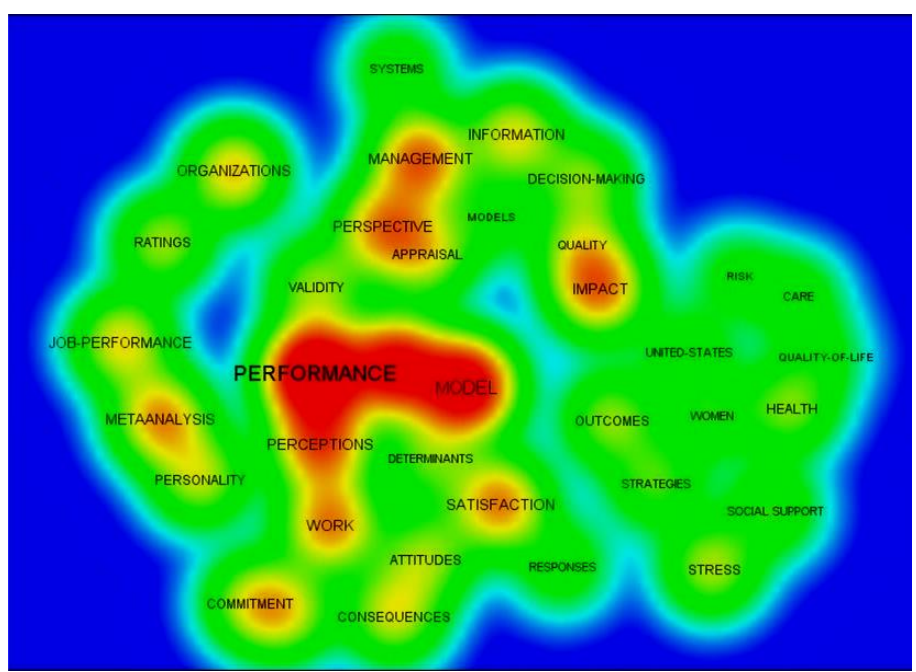

FIGURE IV. DENSITY MAP OF RESEARCH FOCUSES FROM DISCIPLINES CITING AAT
2) The Knowledge-Mapping of research focuses from disciplines cited by $A A T$

Table 5 is the frequency statistics of research focuses from disciplines cited by AAT. These research focuses are almost the same as those in Table 3, but there are some differences in the ranking of the focuses. The data in the table suggests that the development of AAT is closely related to the developments of other disciplines with AAT continuously interacting with other disciplines to improve itself to meet their needs. Figure 7 and 8 are respectively the mapping of relationships between research focuses from disciplines cited by AAT and the density map of these research focuses.

TABLE III. THE FREQUENCIES OF CITED RESEARCH FOCUSES FROM THE DISCIPLINES CITING AAT (FREQUENCY >800)

\begin{tabular}{|c|c|c|}
\hline Freq & Keyword & Main Application Disciplines \\
\hline 6092 & PERFORMANCE & $\begin{array}{c}\text { Business \& Economics,Human Resource } \\
\text { Management ,Psychology }\end{array}$ \\
\hline 4661 & MODEL & Many disciplines \\
\hline 3040 & BEHAVIOR & Psychology \\
\hline 2733 & SATISFACTION & $\begin{array}{l}\text { Information Science \& Library Science, } \\
\text { Education \& Educational Research }\end{array}$ \\
\hline 2533 & MANAGEMENT & Management \\
\hline 2126 & IMPACT & Environmental Science \\
\hline 1893 & PERCEPTIONS & Psychology \\
\hline 1718 & PERSPECTIVE & Business \& Economics ,Management \\
\hline 1628 & INFORMATION & $\begin{array}{c}\text { Information Science \& Library Science, } \\
\text { Computer Science }\end{array}$ \\
\hline 1622 & WORK & $\begin{array}{c}\text { Information Science \& Library Science, } \\
\text { Archival Science, Psychology, } \\
\text { Management }\end{array}$ \\
\hline 1586 & META ANALYSIS & Medical Science, Psychiatry, Psychology \\
\hline 1439 & ORGANIZATIONS & Sociology, Management \\
\hline 1360 & $\begin{array}{l}\text { DECISION- } \\
\text { MAKING }\end{array}$ & Business \& Economics, Computer Science \\
\hline 1326 & APPRAISAL & Business \& Economics, Archival Science \\
\hline 1309 & HEALTH & Medical Science, Psychology \\
\hline 1177 & STRESS & Medical Science, Psychiatry, Psychology \\
\hline 1155 & VALIDITY & $\begin{array}{c}\text { Psychology, Psychiatry, Medical Science, } \\
\text { Computer Science, Business Economics, } \\
\text { Architecture }\end{array}$ \\
\hline 1090 & CONSEQUENCES & Law \\
\hline 1078 & PERSONALITY & $\begin{array}{c}\text { Psychology, Education \& Educational } \\
\text { Research, Psychiatry, Law }\end{array}$ \\
\hline 1062 & QUALITY & $\begin{array}{l}\text { Education, Environmental Science, } \\
\text { Information Science \& Library Science }\end{array}$ \\
\hline 1060 & OUTCOMES & Medical Science, Hygiene, Management \\
\hline 996 & UNITED-STATES & uncertain \\
\hline 988 & CARE & $\begin{array}{l}\text { Medical Science, Medical and Health, } \\
\text { Hygiene, Information Science \& Library } \\
\text { Science }\end{array}$ \\
\hline 981 & $\begin{array}{l}\text { SOCIAL } \\
\text { SUPPORT }\end{array}$ & $\begin{array}{l}\text { Psychology, Education \& Educational } \\
\text { Research, Psychiatry, Medical Science }\end{array}$ \\
\hline 977 & RATINGS & $\begin{array}{c}\text { Finance, Macroeconomic Management and } \\
\text { Sustainable Development }\end{array}$ \\
\hline 971 & WOMEN & Sociology \\
\hline
\end{tabular}




\begin{tabular}{|c|c|c|}
\hline 962 & ATTITUDES & Medical Science, Education, Psychology \\
\hline 940 & STRATEGIES & $\begin{array}{l}\text { Business Economics, Education \& } \\
\text { Educational Research, Psychology }\end{array}$ \\
\hline 933 & $\begin{array}{l}\text { QUALITY-OF- } \\
\text { LIFE }\end{array}$ & Medical Science \\
\hline 933 & SYSTEMS & Computer Science \\
\hline 925 & RISK & $\begin{array}{c}\text { Finance, Medical Science, Business } \\
\text { Economics }\end{array}$ \\
\hline 812 & COMMITMENT & $\begin{array}{l}\text { Management, Psychology, Business \& } \\
\text { Economics, Sociology and Statistics, Law }\end{array}$ \\
\hline 803 & DETERMINANTS & $\begin{array}{l}\text { Business Economics, Macroeconomic } \\
\text { Management and Sustainable Development }\end{array}$ \\
\hline 803 & RESPONSES & Medical Science \\
\hline
\end{tabular}

TABLE IV. THE FREQUENCY STATISTICS OF DISCIPLINES CITED BY AAT (FREQUENCY>100)

\begin{tabular}{|c|c|}
\hline Freq & Disciplines \\
\hline 2371 & Business \& Economics \\
\hline 968 & Psychology \\
\hline 683 & Social Sciences - Other Topics \\
\hline 559 & Public Administration \\
\hline 292 & $\begin{array}{c}\text { Information Science \& Library } \\
\text { Science }\end{array}$ \\
\hline 267 & History \\
\hline 246 & Family Studies \\
\hline 219 & Social Work \\
\hline 218 & Communication \\
\hline 214 & Health Care Sciences \& Services \\
\hline 193 & Environmental Sciences \& Ecology \\
\hline 178 & Urban Studies \\
\hline 171 & Computer Science \\
\hline 151 & Government \& Law \\
\hline 148 & Philosophy \\
\hline 147 & $\begin{array}{c}\text { Public, Environmental \& Occupational } \\
\text { Health }\end{array}$ \\
\hline 120 & Anthropology \\
\hline 120 & Sport Sciences \\
\hline 116 & $\begin{array}{l}\text { Operations Research \& Management } \\
\text { Science }\end{array}$ \\
\hline 115 & Sociology \\
\hline 100 & Medical Informatics \\
\hline
\end{tabular}

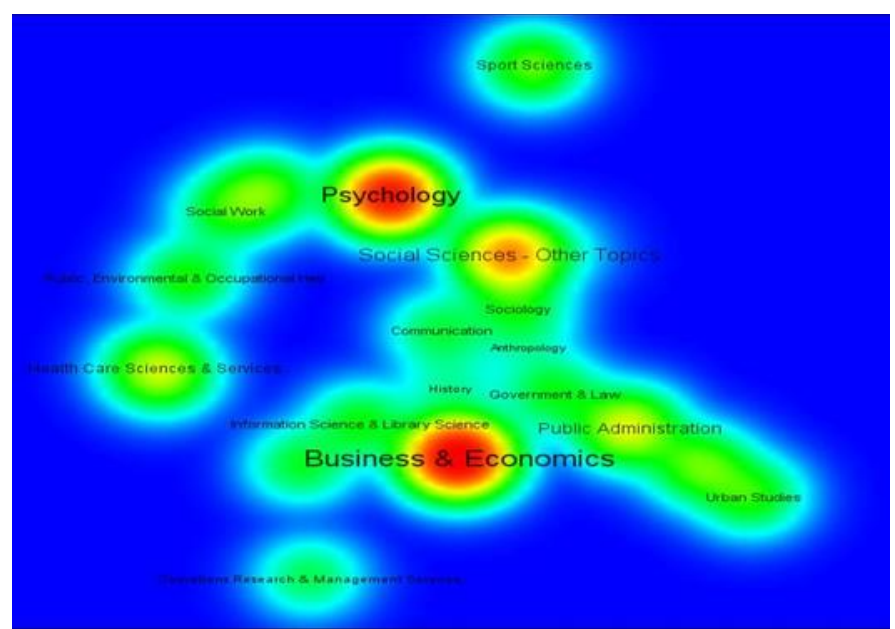

FIGURE V. MAPPING OF RELATIONSHIP BETWEEN DISCIPLINES CITED BY AAT

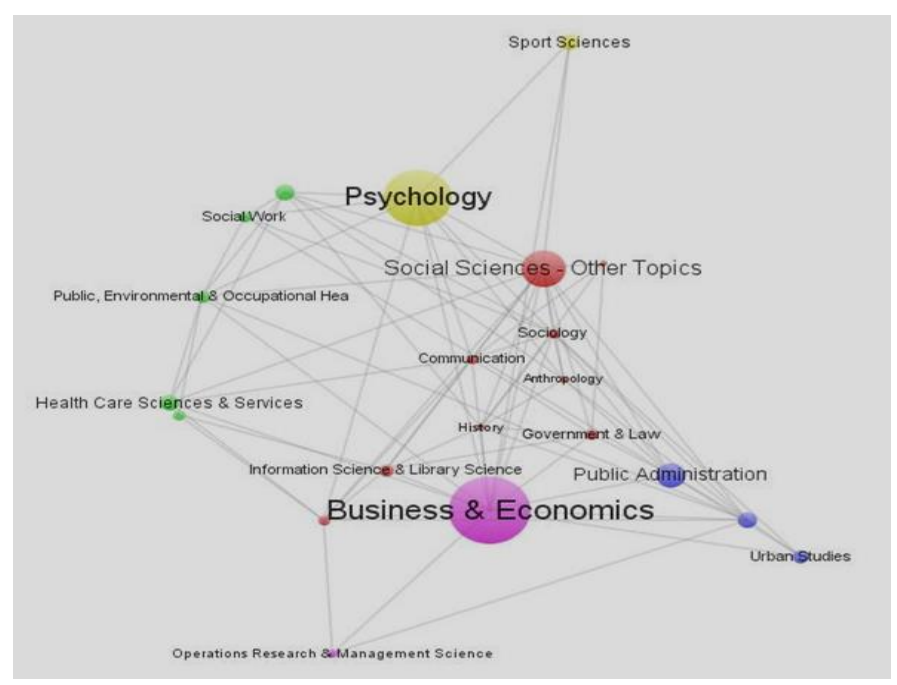

FIGURE VI. DENSITY MAP OF DISCIPLINES CITED BY AAT

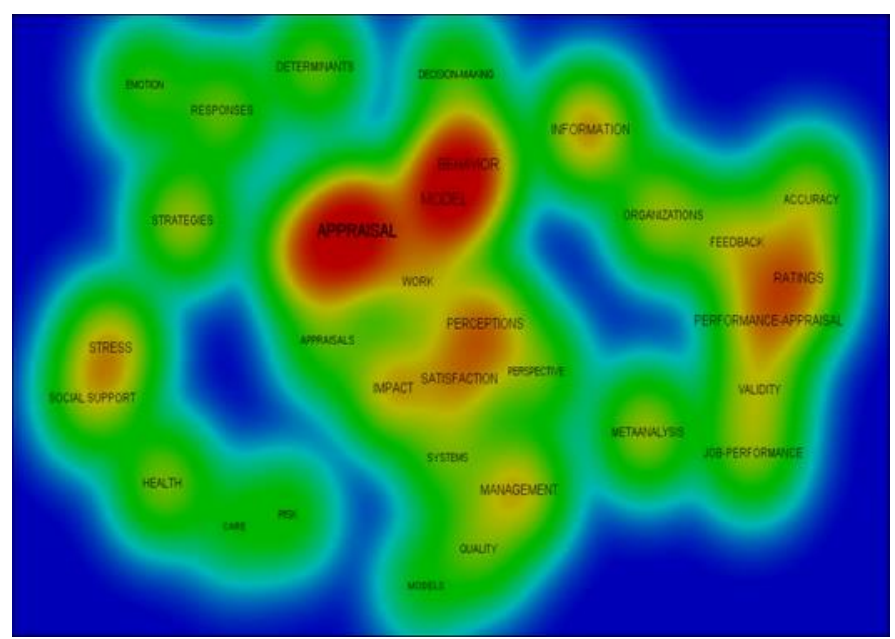

FIGURE VII. MAPPING OFRELATIONSHIP BETWEEN RESEARCH FOCUSES FROM DISCIPLINES CITED BY AAT 


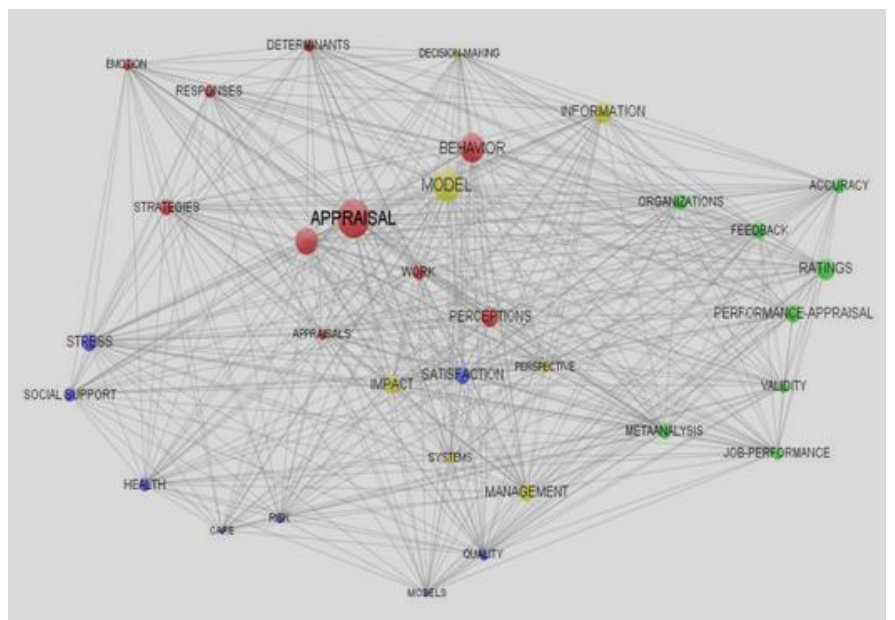

FIGURE VIII. DENSITY MAP OF RELATIONSHIPS BETWEEN RESEARCH FOCUSES FROM DISCIPLINESCITED BY AAT

TABLE V. THE FREQUENCY STATISTICS OF RESEARCH FOCUSES FROM DISCIPLINES CITED BY AAT (FREQUENCIES > 60)

\begin{tabular}{|c|c|c|}
\hline Freq & Keyword & Main Application Disciplines \\
\hline 529 & APPRAISAL & $\begin{array}{l}\text { Business \&Economics,Archival } \\
\text { Science }\end{array}$ \\
\hline 319 & MODEL & Many disciplines \\
\hline 269 & $\begin{array}{l}\text { PERFORMAN } \\
\text { CE }\end{array}$ & Business \& Economics \\
\hline 177 & BEHAVIOR & Psychology \\
\hline 137 & $\begin{array}{l}\text { MANAGEME } \\
\text { NT }\end{array}$ & Management \\
\hline 125 & IMPACT & Environmental Science \\
\hline 120 & $\begin{array}{l}\text { INFORMATIO } \\
\mathrm{N}\end{array}$ & $\begin{array}{l}\text { Information Science \& Library } \\
\text { Science,Computer Science }\end{array}$ \\
\hline 113 & $\begin{array}{c}\text { PERCEPTION } \\
\mathrm{S}\end{array}$ & Psychology \\
\hline 105 & STRESS & $\begin{array}{c}\text { Medical } \\
\text { Science,Psychiatry,Psychology }\end{array}$ \\
\hline 103 & HEALTH & Medical Science,Psychology \\
\hline 100 & RATINGS & $\begin{array}{l}\text { Finance,Macroeconomic Management } \\
\text { and Sustainable Development }\end{array}$ \\
\hline 99 & $\begin{array}{l}\text { SATISFACTIO } \\
\mathrm{N}\end{array}$ & $\begin{array}{c}\text { Psychology,Management,Medical } \\
\text { Science }\end{array}$ \\
\hline 88 & $\begin{array}{c}\text { META } \\
\text { ANALYSIS }\end{array}$ & $\begin{array}{c}\text { Medical } \\
\text { Science,Psychiatry,Psychology }\end{array}$ \\
\hline 82 & STRATEGIES & $\begin{array}{l}\text { Business Economics,Education \& } \\
\text { Educational Research, Psychology }\end{array}$ \\
\hline 82 & RISK & $\begin{array}{l}\text { Finance,MedicalScience,Business\& } \\
\text { Economics } \\
\text { Information Science \& Library }\end{array}$ \\
\hline 78 & WORK & $\begin{array}{c}\text { Information Science \& Library } \\
\text { Science, Archival } \\
\text { Science,Psychology,Management }\end{array}$ \\
\hline 76 & $\begin{array}{l}\text { SOCIAL } \\
\text { SUPPORT }\end{array}$ & $\begin{array}{l}\text { Psychology,Education \& Educational } \\
\text { Research, Psychiatry,Medical Science } \\
\text { Psychology,Psychiatry,MedicalScience }\end{array}$ \\
\hline 76 & VALIDITY & $\begin{array}{c}\text {, ComputerScience,Business } \\
\text { Economics,Architecture }\end{array}$ \\
\hline 73 & RESPONSES & Medical Science \\
\hline 72 & SYSTEMS & Computer Science \\
\hline 72 & QUALITY & $\begin{array}{l}\text { Education,EnvironmentalScience, Infor } \\
\text { mation Science \& Library Science }\end{array}$ \\
\hline
\end{tabular}

\begin{tabular}{|c|c|c|}
\hline 71 & $\begin{array}{l}\text { ORGANIZATI } \\
\text { ONS }\end{array}$ & Sociology,Management \\
\hline 70 & PERSPECTIVE & Business \& Economics ,Management \\
\hline 68 & $\begin{array}{l}\text { DECISION- } \\
\text { MAKING }\end{array}$ & $\begin{array}{l}\text { Business \&Economics,Computer } \\
\text { Science }\end{array}$ \\
\hline 68 & FEEDBACK & Computer,SportSciences,Education \\
\hline 67 & ACCURACY & Medical Science,Computer \\
\hline 65 & $\begin{array}{l}\text { DETERMINA } \\
\text { NTS }\end{array}$ & $\begin{array}{l}\text { Business \&Economics,Medical and } \\
\text { Health, Computer Science } \\
\text { Medical Science,Medical and Health, }\end{array}$ \\
\hline 63 & CARE & $\begin{array}{c}\text { Hygiene,Library and Information and } \\
\text { Digital Library }\end{array}$ \\
\hline 61 & EMOTION & $\begin{array}{c}\text { Psychology,SportSciences,Clinical } \\
\text { medicine }\end{array}$ \\
\hline
\end{tabular}

\section{CONCLUSION}

The development trends of AAT in the past almost three decades can be extrapolated, and the conclusions can be made, based on the analysis on the disciplines and their research focuses that have cited AAT and been cited by AAT.

\section{A. Trend 1: the Declining Influences by Historicism}

The emergence and development of archival science was closely related to the study of History. So to speak, archival science in the early stage can be considered as a by-product of History study. The influence of historicism even spurred the formation of "Utilization Determination Theory" of AAT, which regards historians' actual and expected utilizations of archives as the most important criteria in archival appraisal.

However, the influence by Historicism on AAT has been declining in the past almost thirty year and this trend can be reflected in the table of frequency statistics of disciplines cited by AAT. It shows that the influence on AAT by History study has declined (currently the sixth in the rank of disciplines cited by AAT) and is no longer the most influential discipline to the development of AAT. In the meanwhile, the standards of AAT have become more diversified. Moreover, since the emergence of electronic archives, the attentions paid to electronic archival appraisal exceeded those paid to content (historical paper documents) appraisal. The establishment of "Double Point Theory" for electronic archival appraisal demonstrated the weakening of Historicism in guiding AAT developments. In addition, archives' properties as technological devices have become popular research focuses of AAT.

\section{B. Trend 2: the Regression to Function Appraisal Theory}

Since late 1980s, with the astonishing increase of archival quantities, growing complexity of archival types, and the fast growing applications of archives, archival researchers have been gradually convinced that archives should reflect the societal values that influenced the archives' productions. As a result, the ideological basis of archival theory has undergone a fundamental change from being a national theory to being a societal one. However, later on, the focuses of archival appraisal have gradually shifted from an archive's complex societal values (and the social problems or trends they intent to convey) to the archival provenances shown by the functions of archival creators. The analysis would emphasize on the functions of archival creators, their activities and 
interrelationships in those activities, and their importance (standings) in business, etc. This new trend, albeit based on the same concept behind the old "Functional Appraisal Theory" (FAT), demands a large body of knowledge from other disciplines to assist archival appraisal, such as Public Administration, Information Storage and Retrieval. The table of frequency statistics of disciplines that have cited AAT and been cited by AAT shows the trend that Public Administration, Information Science \& Library Science have been more important than History as far as the influence on AAT is concerned, confirming partially the regressions to FAT.

\section{Trend 3: the Predominant Popularity of Provenance Principle ( $P P)$}

$\mathrm{PP}$ is a way to "compartmentalize and manage archives on their provenances to the organizations producing those archives". It means archival workers arrange and classify the archives according to archival provenance and must stick to the principle that "Do not disperse the archives from the same provenance, and do not mix up the archives from different provenances". In view of archival value, the principle emphasizes that the archival preservation value should be appraised based on the creators' functions and the functions of the archives they create. PP had been derived from principle of "Respect General Archives" that originated in France in 1841. The appraisal standards and approaches based on PP are simpler, more objective and practical, hence is an important criterion to judge archival value.

PP made it possible that the applications of AAT to different disciplines. According to the data collected from 1990 to 2017, we could arrive at a conclusion that the disciplines citing AAT and cited by AAT are widely distributed, it shows that all those different disciplines were applying AAT to their own research fields using a variety of different AAT methods, and the methods used depend on the different disciplines and organizations that produce those archives. It reveals that PP is indeed a highly important, or in other words predominant, component of AAT.

\section{Trend 4: the Practicalization of Appraisal Standards}

In the past thirty years, the practicalizations of archival appraisal theories has grown to be more obvious. This trend can be shown in two aspects as follows:

First, the criteria of archival appraisal have been made more favorable to practical application and systematization. In face of the rapid rise of archival quantities, it is very important to make a prompt decision on archival appraisal in time. The procedure for archival appraisal instructions has been made to further detail the storage time of archives in order to facilitate archival appraisal workers to utilize specific methods in a prompt manner. This development trend can be reflected on the research focuses from disciplines that have cited AAT and been cited by AAT, such as the keywords of ORGANIZATIONS, SYSTEMS.

Second, archival appraisal is the main measure for archive optimization. Among a huge collection of files and documents, only a small part of it could be worth being conserved permanently as archives. Therefore, it is essential to control the size of archival collections and to guarantee their qualities at the same time. Archival optimization means to obtain the best proportional relationship between the size of an archival collection and its quantity of information, in other words, how to conserve the maximal amount of necessary information with the minimal size of archival collection. This development trend of archival appraisal can be reflected on the keywords in the articles of collection optimization in AAT, such as MODEL, STRATEGIES, VALIDITY, and QUALITY.

\section{E. Trend 5: the Increasing Emphasis on Utilitarianism}

The keywords of PERFORMANCE and SATISFACTION enjoy very high rankings in the research focuses from disciplines that have cited AAT and been cited by AAT, and it follows that the emphasis on AAT's utilitarianism (for the utilitarian benefits to the organization that applies AAT) has received more attentions and become an important criterion of archival appraisal.

In addition, evaluating an archive's value given the cost of conserving it, archival workers try their bests to maximize the benefits applying AAT and minimize the cost. The phenomenon shows that the idea of emphasizing benefits in archival appraisal work has been widely accepted. Archival appraisal is no longer limited to basing itself on subjective demands or on objective properties, but it would also rather be skewed to achieve the optimal benefits in different scenarios and for different disciplines.

\section{F. Thoughts}

The development of AAT is both a dynamic and a regular process. We studied this observation and used the study results to discover the trends of AAT developments in the past almost three decades. These discoveries could be used to augment, tune and enrich Archival Science in order to meet the emerging demands for more applicable and effective theories and methods for appraising modern archival works.

\section{ACKNOWLEDGMENT}

This article is supported by Tianjin Municipality Key Project of Philosophy and Social Sciences (TJTQ17-004) and Tianjin Municipality Young and Middle-aged Backbone of Innovative Talents Plans.

\section{REFERENCES}

[1] Barbara Lazenby Craig,Archival Appraisal: Theory and Practice. Walter de Gruyter, 224, 2004

[2] Brubach, N., "Appraisal in archival treatment in Germany", Fontes Artis Musicae, Jul-Sep, 43: 259-270, 1996

[3] Cathelijn J. F. Waaijer, Cornelis A. van Bochove, and Nees Jan van Eck., "On the map: Nature and Science editorials", Scientometrics, January, 86(1): 99-112, 2011

[4] Caroline M. Williams, Managing archives: foundations, principles and practice, Chandos information professional series, Chandos, 248, 2006

[5] Chaomei Chen, Katherine McCain, Howard White, Xia Lin,"Mapping Scienteomtrics", ASIST, 29:25-34, 2002

[6] Cheryl Avery, Mona Holmlund, Better Off Forgetting?: Essays on Archives, Public Policy, and Collective Memory, University of Toronto Press, 242, 2010 
[7] Cook Terry, "We Are What We Keep; We Keep What We Are: Archival Appraisal Past, Present and Future", Journal of the Society of Archivists, 32: 173-189, 2011

[8] David W. Carmicheal, Organizing Archival Records: A Practical Method of Arrangement and Description for Small Archives, AltaMira Press, 85, 2004

[9] Duranti, L, "The concept of appraisal and archival theory", American Archivist, Spr. 57: 328-344, 1994

[10] Eck, N.J.P. van, "Methodological Advances in Bibliometric Mapping of Science. ERIM PhD Series Research in Management", The Netherlands, $147-149,2004$

[11] Elsie $\mathrm{T}$ Freeman Finch, "In the eye of the beholder: Archives administration from the user's point of view", American Archivist, 47:112-119, 1984

[12] Erjia Yan, Ying Ding, Elin K. Jacob, "Overlaying communities and topics: an analysis on publication networks", Scientometrics, February, 90(2): 499-513, 2012

[13] Frank Boles, Selecting and appraising archives and manuscripts. Archival fundamentals series. Society of American Archivists, 193, 2005

[14] Garaba Francis, "The state of archival appraisal practices in the ESARBICA region", African Journal of Library Archives and Information Science. Apr. 17: 59-63, 2007

[15] HurleyC., "Archival appraisal: Theory and practice", Journal of the Society of Archivists, Apr., 26: 143-146, 2005

[16] Marc H. Anderson, "Social networks and the cognitive motivation to realize network opportunities: a study of managers' information gathering behaviors", Journal of Organizational Behavior.29:1, 51-78, 2008

[17] Mayer H. Fishbein, "A viewpoint on appraisal of national records", American Archivist, 4:175, 1970

[18] M.E.J.Newman, "The Structure of Scientific Collaboration Networks", inProceedings of the National Academy of Sciences of the USA,January 16,98(2): 404-409, 2001

[19] Menzi L. Behrnd-Klodt, and Peter J. Wosh, Privacy and Confidentiality Perspectives Archivists and Archival Records, Amer Library Assn, 391, 2009

[20] Michael J. Kurtz., "Managing archival and manuscript repositories. Archival fundamentals series", Society of American Archivists, 255, 2004

[21] Nees Jan van Eck, Ludo Waltman, "Software survey: VOSviewer, a computer program for bibliometric mapping", Scientometrics, August, 84(2): 523-538, 2010

[22] Ngulube, P., "Archival appraisal and the future of historical research in Southern Africa", South African Historical Journal, Nov., 249-265, 2001

[23] Richard J. Cox, Archives \& archivists in the information age, The archivist's and records manager's bookshelf, Neal-Schuman Publishers,325, 2005

[24] Richard Pearce-Moses, A glossary of archival and records terminology. Archival fundamentals series, Society of American Archivists, 433,2005

[25] Stanley. Wasserman, K. Faust, Social Network Analysis: Methods and Application. Cambridge, NY: Cambridge University Press, 44-52, 1994

[26] Steven L. Hensen, Describing archives: a content standard, Society of American Archivists, 269, 2004

[27] V. S. Harris, Archives and justice: a South African perspective, Society of American Archivists, 447, 2007. 